EGU21-2868, updated on 18 May 2021

https://doi.org/10.5194/egusphere-egu21-2868

EGU General Assembly 2021

(c) Author(s) 2021. This work is distributed under

the Creative Commons Attribution 4.0 License.

\title{
Earth Scientist and Social Media: approaching our planet to young people and general public using comics and illustration.
}

\author{
Stefania Schamuells ${ }^{1}$, Olaya Dorado ${ }^{1,2}$, Joaquin Hopfenblatt ${ }^{2}$, Meritxell Aulinas ${ }^{1}$, and Adelina \\ Geyer $^{2}$ \\ ${ }_{1}^{1}$ Departament de Mineralogia, Petrologia i Geologia Aplicada, University of Barcelona, Marti Franques s/n, 08028, \\ Barcelona, Spain (sschamuells@gmail.com; olayadorado@gmail.com; \\ ${ }^{2}$ Geosciences, GEO3BCN - CSIC, Lluis Sole i Sabaris s/n, 08028, Barcelona, Spain (joaquinhopfenblatt@gmail.com; \\ ageyer@geo3bcn.csic.es)
}

Earth Sciences are booming in social media, an unexampled scenario a few years ago. In the last year, these numbers have increased because of the COVID-19, citizens are consuming even more digital information, at the same time they are looking for more simplified and easy-understanding scientific concepts. It is very important to remark the value of entertainment, humor, and visual contents, which have a light universal language to approach Earth Sciences to citizens and experts beyond the pure academic frontiers. In this work, we share some successful examples through the use of illustration, comic, and infographic content between two Instagram accounts (@ohmagmamia and @salirconunageologa) which addend more than 13,000 followers and have a potential reach up to $37.1 \mathrm{k}$ (based on their account insights). The audience for this content is international although it has gained great popularity among the Spanish-speaking public (the initial target audience), little by little creating an interesting and growing movement. Countries such as Chile, Argentina, Colombia, and Spain have the greatest impact according to statistics. Age range is between $18-34$ years for $87 \%$ of the audience, with a clearly female predominance $(55 \%$ in @Ohmagmamia and 60\% in @Salirconunageologa).

One of the principal goals of these accounts is to develop visual, artistic and easy-understanding content that fits the audience. On one hand @Ohmagmamia uses photographic material (e.g. landscapes, outcrops, hand specimen samples or micro-photographies), simple geological sketches and infographic content along with small descriptions in the post captions. This approach has been well received by both Earth Science students and non-professional enthusiasts, as well as biology-geology teachers and public examination trainers. On the other hand, @Salirconunageologa (Dating a geologist) uses cartoons, humour and comics to approach Earth Sciences to professionals and the general public. Its visual material focuses on storytelling to explain what it means to be a geologist using all its universe of friendly characters. In the first season of "Dating a Geologist Universe" (with 17 episodes), the main character, Nia Stone, is involved in different hilarious situations related to Earth Sciences, like volcanoes, trilobites, or Dr. Gems (the main Villain). This "geocomics" have been very well received, being the first chapter the one which records the best audience data, with 10k accounts reached on Instagram. 
Social media statistics data provide interesting information about the success of these scientific dissemination's new methods. In the last 6 months of the 2020 both accounts reached an average of 11,000 Instagram accounts with an average more than 1,000 "likes" per post and with an engagement rate that varies from 9 to $12 \%$. In addition, the use of other social media such as Twitter or YouTube able us to reach more people and/or accounts by using Twitter "threads" or sharing videos of invite talks or "webinars", whose popularity grew during the quarantine period. All these results show the importance of a perfect relation between visuals, art and Earth Science and its capability to reach people from all around the globe. 